(Received June 19, 1986)

\title{
CONFORMATION OF FRAGMENTS FROM DEGRADATION OF WOOL-Cu(II) COMPLEX BY HYDROGEN PEROXIDE
}

\author{
By Kazuhiko Fukatsu and Mariko Isa \\ (Faculty of Living Science, Kumamoto Women's University, \\ Kengun-machi, Kumamoto 862, Japan)
}

\begin{abstract}
The fragments from the degradation of wool-Cu(II) complex by hydrogen peroxide have a partly ordered structure ( $\alpha$-helix) in water. As the $\mathrm{pH}$ increases, the partly ordered structure transforms into a random coil. Further, the fragments undergo random coil- $\alpha$-helix transition in ethanol-water mixtures with increasing ethanol component. These behaviors are similar to those of charged polyamino acids, in spite of that the fragments of wool undergo a less sharp transition in comparison with charged polyamino acids.
\end{abstract}

\section{INTRODUCTION}

Three distinct fragments of protein were isolated from $\alpha$-keratin; the low-sulphur fragment, the high-sulphur fragment and the high-glycine-tyrosine fragment ${ }^{1}$. These fragments were examined by means of the X-ray diffraction, infrared absorption and circular dichroism methods, and were shown to have ordered structures such as $\alpha$-helix or $\beta$ conformation in solution and in solid state.

Inagaki and coworkers ${ }^{2,3)}$ investigated the conformations of a high-sulphur and a high-glycine fragments from wool keratin and found that these tend to form partly $\beta$-conformation in the films cast from formic acid solution. Crewther and coworker $^{4}$ ) showed that the fractions obtained by partial chymotryptic digestion of S-carboxymethyl derivatives of the low-sulphur fragment have an $\alpha$-helix content of about $83 \%$ in borate solution.

It is well known ${ }^{5)}$ that wool-Cu(II) complex is easily obtained by a reaction of wool with copper(II) ion. With a view to obtaining functional protein metal complexes we examined the complexation of wool keratin and found that $\mathrm{Cu}$ (II) complex of wool can be degraded by hydrogen peroxide $\left(\mathrm{H}_{2} \mathrm{O}_{2}\right)$ more readily than that of silk fibroin. We consider it to be interesting to clarify the conformation of these degraded fragments and the composition of polypeptide species contained in them. The present communication deals with a circular dichroism (CD) study on conformations of these fragments of wool-Cu(II) complex in water or in ethanol-water mixtures.

\section{EXPERIMENTAL}

Wool keratin fiber was employed in the form of woven fabric cloth made up from Merino 64's quality wool. All other chemicals were of reagent grade and were used without further purification.

The sample fragments were prepared from wool$\mathrm{Cu}$ (II) complex as follows: Sample of wool fiber $(10 \mathrm{~g})$ was added in $150 \mathrm{ml}$ aliquot of $2.7 \times 10^{-2} \mathrm{M}$ $\mathrm{Cu}\left(\mathrm{NO}_{3}\right)_{2}$ aqueous solution, and the flask was shaken to facilitate the wetting-out of the fiber, followed by the addition of $400 \mathrm{ml}$ of $0.25 \mathrm{~N}$ $\mathrm{NaOH}$ aqueous solution to make wool-Cu(II) complex. Then three $15 \mathrm{ml}$ portions of $30 \% \mathrm{H}_{2} \mathrm{O}_{2}$ aqueous solution were added at two hours intervals. The reaction mixture thus prepared was allowed to be shaken at room temperature until the wool fiber was no longer detactable. After the reaction had completed, conc. $\mathrm{HCl}$ was added to adjust the $\mathrm{pH}$ of reaction mixture at about 6 . The mixture was filtered and the filtrate was then dialyzed against distillated water; the resultant turbid solution was centrifuged to remove insoluble materials. 
The $\mathrm{pH}$ of the solution was 6.54. The concentration of $\mathrm{Cu}(\mathrm{II})$ ion was $2.24 \times 10^{-5} \mathrm{M}$, being negligibly low. The concentration of sample fragments was $4.18 \mathrm{~g} / \mathrm{l}$. Assuming that the amino acid composition was not changed by the degradation, its apparent molar concentration of mean residue was estimated as $3.3 \times 10^{-2} \mathrm{M} / \mathrm{l}$.

$\mathrm{CD}$ measurements of the sample fragments solutions were obtained on a Jasco J-40 spectropolarimeter in the region of $200-260 \mathrm{~nm}$ at room temperature. The $\mathrm{CD}$ spectra were expressed in the term of molar ellipticity using the apparent molar concentration of the solution.

\section{RESULTS}

Figure 1 shows the $\mathrm{CD}$ spectra of sample fragments in aqueous solution at various $\mathrm{pH}$. The fragments in water exhibit a $\mathrm{CD}$ spectrum characteristic of a helix with a double minimum at 222 and $206 \mathrm{~nm}$, though the residue ellipticities values $[\theta]$ at both wavelength are small (Figure 1 , curve a) and decrease with rising the $\mathrm{pH}$ (Figure 1, curve b, $c)$, suggesting that the fragments tested contain partially ordered structure ( $\alpha$-helix), which undergoes a transition from the $\alpha$-helix to the random coil. This fact is possibly due to the electrostatic repulsion between involved anionic functional groups in an analogy with poly-L-glutamic acid ${ }^{6}$,

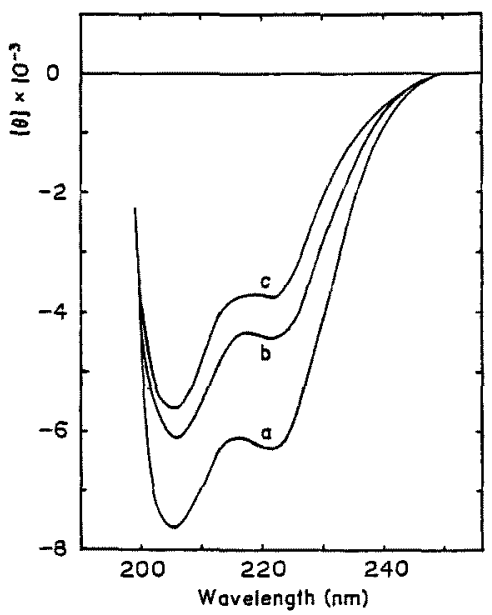

Fig. 1. CD spectra of the fragments of wool-Cu(II) complex degraded with $\mathrm{H}_{2} \mathrm{O}_{2}$ obtained in water at different $\mathrm{pH}$.

Curve a, $\mathrm{pH}=5.25$; curve $b, 7.85$; curve $c$, 10.40 . because the dissociation of the charged side chains (glutamyl and aspartyl residues) in the system will be promoted as the $\mathrm{pH}$ increases.

It is well known ${ }^{7,8)}$ that the addition of alcohol to an aqueous solution of polypeptides enhances the helix stability. Pispisa and coworker ${ }^{9}$ reported on the basis of some experimental evidences that the role of organic solvent in solution appears more complicated than that of strengthening the intramolecular hydrogen bonds within the polymer. A similar result was obtained in this investigation. Figure 2 shows the $C D$ spectra of the sample fragments in ethanol-water mixtures. As the ethanol ratio increases, the $\alpha$-helix content induced, as indicated by the change of CD spectra (Figure 2, curves $b \sim g$ ), but the transition shown by the fragments of wool was not so sharp as that for the formation of fully charged $\alpha$-helical structures. In the insert of Figure 2, the values of

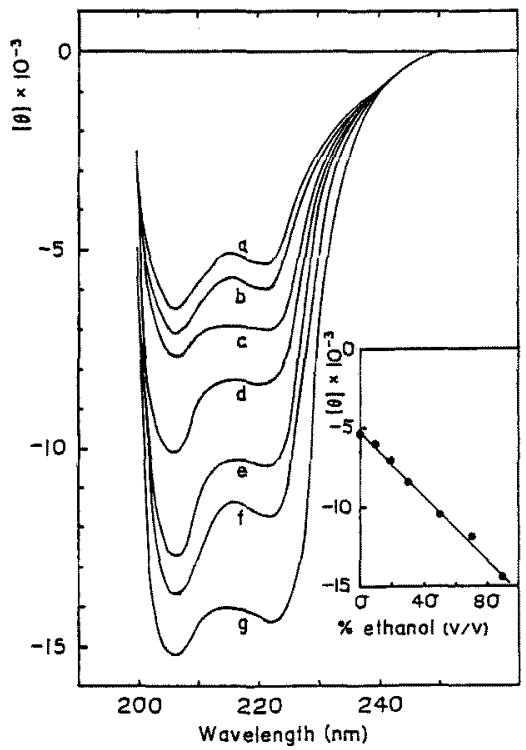

Fig. 2. $\mathrm{CD}$ spectral changes of the fragments of wool-Cu(II) complex degraded with $\mathrm{H}_{2} \mathrm{O}_{2}$ as a function of ethanol concentration (by vol.).

Curve a, $0 \%$ ethanol ( $\mathrm{pH}=6.54)$; curve $\mathrm{b}$, $10 \%$; curve c, $20 \%$; curve $d, 30 \%$; curve e, $50 \%$; curve $\mathrm{f}, 70 \%$; curve $\mathrm{g}, 90 \%$.

All curves were recorded immediately after preparation of solutions.

Insert: Variation of ellipticity at $222 \mathrm{~nm}$ as a function of solvent composition in terms of \% ethanol. 
[ $\theta]$ at $222 \mathrm{~nm}$ gradually changed with increasing ethanol component.

The present results indicate that the fragments from the degradation of wool-Cu(II) complex by $\mathrm{H}_{2} \mathrm{O}_{2}$ have a conformational transition in water and ethanol-water mixtures in a similar manner as those found for charged polyamino acids.

\section{ACKNOWLEDGEMENT}

The authors wish to thank Prof. Hiroyuki Yamamoto of the Institute of High Polymer Research, Shinshu University, for useful suggestion and for affording facilities for the CD measurements.

\section{REFERENCES}

1) W. G. Crewther, R. D. B. Fraser, F. G. Lennox and H. Lindley; Advan. Protein Chem., 20, 191 (1965).

2) T. Amiya, A. Kawaguchi, T. Miyamoto and $H$. Inagaki; Sen-i Gakkaishi, 36, T-479 (1980).

3) T. Amiya, T. Miyamoto and H. Inagaki; Biopolymers, 19, 1093 (1980).

4) W. G. Crewther and L. M. Dowling; Appl. Polym. Symp., No. 18, 1 (1971).

5) S. Kokot, M. Feughelman and R. M. Golding; Textile Res. J., 42, 704 (1972).

6) P. Doty, A. Wada and J. T. Yang; J. Polymer Sci., 23, 851 (1957).

7) T. V. Barskaya and O. B. Ptitsyn; Biopolymers, 10, 2181 (1971).

8) H. Yamamoto and J. T. Yang; Biopolymers, 13, 1109 (1974).

9) M. Barteri and B. Pispisa; Biopolymers, 12, 2309 (1973).

\section{羊毛一銅 (II) 錯体の過酸化水素分解による \\ フラッグメントの二次構造}

\footnotetext{
熊本女子大学生活科学部深律和彦，伊佐真理子

羊毛一銅（I)錯体を過酸化水素で分解して得られたフ ラッグメントの水溶液中及びアルコールー水混合溶媒中

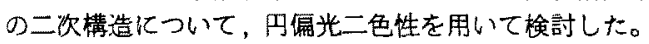
水溶液中で，一部 $\alpha$-ヘリックス構造が形成され， $\mathrm{pH}$ 增加ととも減少した。又，アルコールー水湿合溶媒中

\author{
構造の增加加観測された。これら一連の転移は荷電ポリ \\ アミノ酸(ポリーLーグルタミン酸, ポリーLーリジン,な \\ ぞ）飞観測されたように側鎖解離基にも上づくものと考 \\ えられる。しかし，転移は荷電ポリアミノ酸に較へて， \\ 編慢である。
}

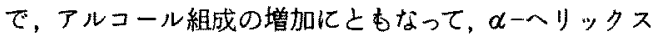

